
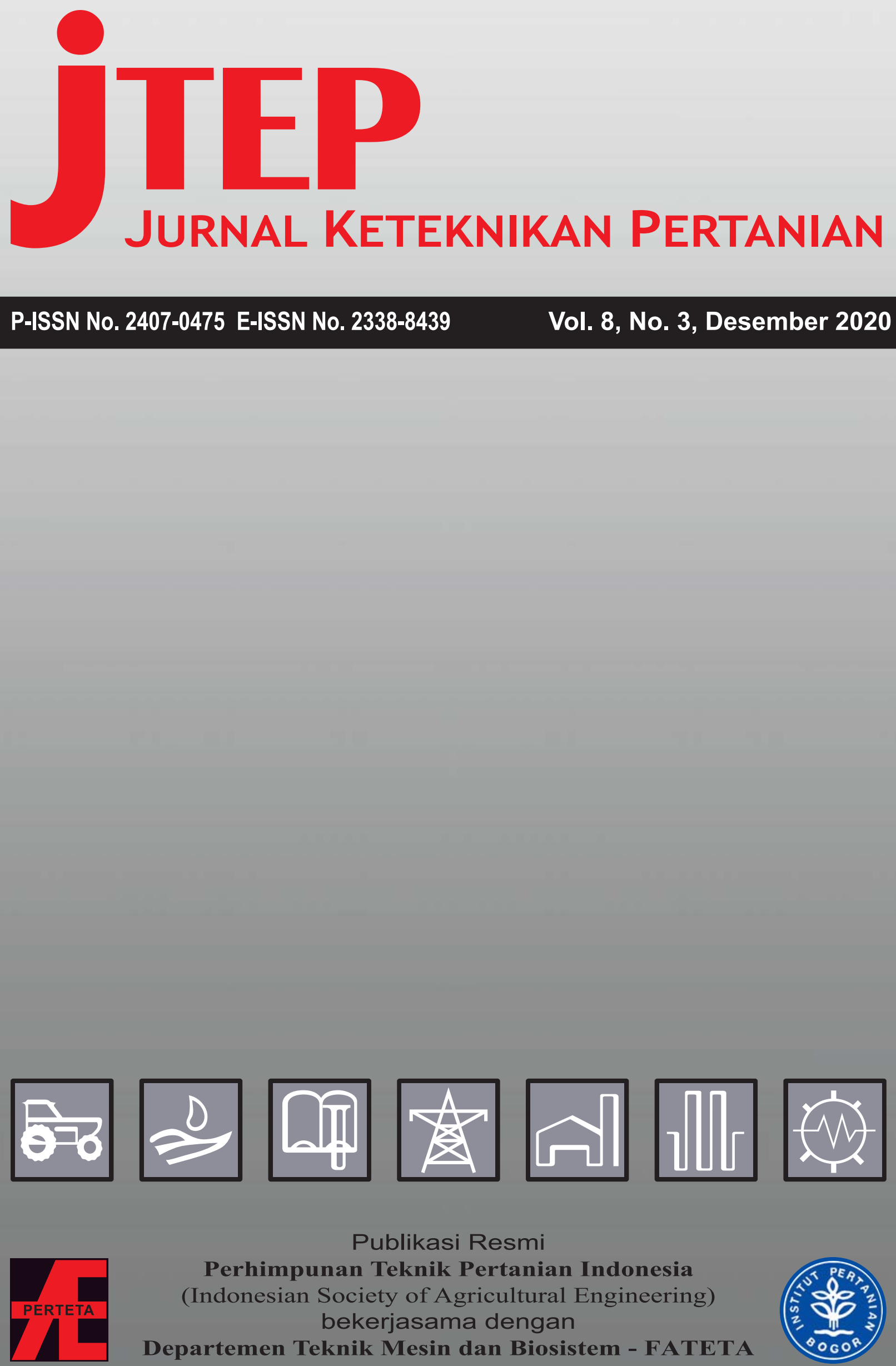

\footnotetext{
Publikasi Resmi

Perhimpunan Teknik Pertanian Indonesia (Indonesian Society of Agricultural Engineering) bekerjasama dengan Departemen Teknik Mesin dan Biosistem - FATETA Institut Pertanian Bogor
}

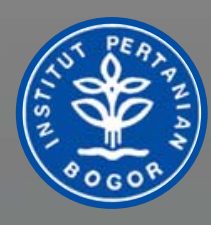




\section{jTEP JURnal Keteknikan Pertanian}

Vol. 8, No. 3, Desember 2020

Jurnal Keteknikan Pertanian (JTEP) terakreditasi berdasarkan SK Dirjen Penguatan Riset dan Pengembangan Kementerian Ristek Dikti Nomor I/E/KPT/2015 tanggal 21 September 2015. Selain itu, JTEP juga telah terdaftar pada Crossref dan telah memiliki Digital Object Identifier (DOI) dan telah terindeks pada ISJD, IPI, Google Scholar dan DOAJ. JTEP terbit tiga kali setahun yaitu bulan April, Agustus dan Desember, Jurnal berkala ilmiah ini berkiprah dalam pengembangan ilmu keteknikan untuk pertanian tropika dan lingkungan hayati. Penulis makalah tidak dibatasi pada anggota PERTETA tetapi terbuka bagi masyarakat umum. Lingkup makalah, antara lain meliputi teknik sumberdaya lahan dan air, alat dan mesin budidaya pertanian, lingkungan dan bangunan pertanian, energi alternatif dan elektrifikasi, ergonomika dan elektronika pertanian, teknik pengolahan pangan dan hasil pertanian, manajemen dan sistem informasi pertanian. Makalah dikelompokkan dalam invited paper yang menyajikan isu aktual nasional dan internasional, review perkembangan penelitian, atau penerapan ilmu dan teknologi, technical paper hasil penelitian, penerapan, atau diseminasi, serta research methodology berkaitan pengembangan modul, metode, prosedur, program aplikasi, dan lain sebagainya. Penulisan naskah harus mengikuti panduan penulisan seperti tercantum pada website dan naskah dikirim secara elektronik (online submission) melalui http://journal.jpb.ac.id/index.php/jtep.

\section{Penanggungjawab:}

Ketua Departemen Teknik Mesin dan Biosistem, Fakultas Teknologi Pertanian,IPB

Ketua Perhimpunan Teknik Pertanian Indonesia

\section{Dewan Redaksi:}

Ketua : Yohanes Aris Purwanto (Scopus ID: 6506369700, IPB University)

Anggota : Abdul Hamid Adom (Scopus ID: 6506600412, University Malaysia Perlis)

(editorial Addy Wahyudie (Scopus ID: 35306119500, United Arab Emirates University)

board) Budi Indra Setiawan (Scopus ID: 55574122266, IPB University)

Balasuriya M.S. Jinendra (Scopus ID: 30467710700 , University of Ruhuna)

Bambang Purwantana (Scopus ID: 6506901423, Universitas Gadjah Mada)

Bambang Susilo (Scopus ID: 54418036400, Universitas Brawijaya)

Daniel Saputera (Scopus ID: 6507392012, Universitas Sriwjaya)

Han Shuqing (Scopus ID: 55039915600, China Agricultural University)

Hiroshi Shimizu (Scopus ID: 7404366016, Kyoto University)

I Made Anom Sutrisna Wijaya (Scopus ID: 56530783200, Universitas Udayana)

Agus Arif Munawar (Scopus ID: 56515099300, Universitas Syahkuala)

Armansyah H. Tambunan (Scopus ID: 57196349366, IPB University)

Kudang Boro Seminar (Scopus ID: 54897890200, IPB University)

M. Rahman (Scopus ID: 7404134933, Bangladesh Agricultural University)

Machmud Achmad (Scopus ID: 57191342583, Universitas Hasanuddin)

Muhammad Makky (Scopus ID: 55630259900, Universitas Andalas)

Muhammad Yulianto (Scopus ID: 54407688300, IPB University \& Waseda University)

Nanik Purwanti (Scopus ID: 23101232200, IPB University \& Teagasc Food Research Center Irlandia)

Pastor P. Garcia (Scopus ID: 57188872339 , Visayas State University)

Rosnah Shamsudin (Scopus ID: 6507783529, Universitas Putra Malaysia)

Salengke (Scopus ID: 6507093353, Universitas Hasanuddin)

Sate Sampattagul (Scopus ID: 7801640861, Chiang Mai University)

Subramaniam Sathivel (Scopus ID: 6602242315, Louisiana State University)

Shinichiro Kuroki (Scopus ID: 57052393500, Kobe University)

Siswoyo Soekarno (Scopus ID: 57200222075, Universitas Jember)

Tetsuya Araki (Scopus ID: 55628028600, The University of Tokyo)

Tusan Park (Scopus ID: 57202780408, Kyungpook National University) 


\section{Redaksi Pelaksana:}

Ketua : : Usman Ahmad (Scopus ID: 55947981500, IPB University)

Sekretaris : Lenny Saulia (Scopus ID: 16744818700, IPB University)

Bendahara : Dyah Wulandani (Scopus ID: 1883926600, IPB University)

Anggota : Satyanto Krido Saptomo (Scopus ID: 6507219391, IPB University)

Slamet Widodo (Scopus ID: 22636442900, IPB University)

Liyantono (Scopus ID: 54906200300, IPB University)

Leopold Oscar Nelwan (Scopus ID: 56088768900, IPB University)

I Wayan Astika (Scopus ID: 43461110500, IPB University)

Agus Ghautsun Niam (Scopus ID: 57205687481, IPB University)

Administrasi : Khania Tria Tifani (IPB University)

Penerbit: Departemen Teknik Mesin dan Biosistem, Institut Pertanian Bogor bekerjasama dengan Perhimpunan Teknik Pertanian Indonesia (PERTETA).

Alamat: Jurnal Keteknikan Pertanian, Departemen Teknik Mesin dan Biosistem, Fakultas Teknologi Pertanian, Kampus Institut Pertanian Bogor, Bogor 16680.

Telp. 0251-8624 503, Fax 0251-8623 026,

E-mail: jtep@apps.ipb.ac.id

Website: http://journal.ipb.ac.id/index.php/jtep

Rekening: BRI, KCP-IPB, No.0595-01-003461-50-9 a/n: Jurnal Keteknikan Pertanian

Percetakan: PT. Binakerta Makmur Saputra, Jakarta 


\section{Ucapan Terima Kasih}

Redaksi Jurnal Keteknikan Pertanian mengucapkan terima kasih kepada para Mitra Bebestari yang telah menelaah naskah pada penerbitan Vol. 8, No. 3 Desember 2020. Ucapan terima kasih disampaikan kepada: Prof.Dr.Ir. Lilik Soetiarso (Universitas Gadjah Mada), Dr.Ir. Lady Lengkey, M.Si (Universitas Sam Ratulangi), Ir. Siti Mariana Widayanti, M.Si, (Balai Besar Penelitian dan Pengembangan Pascapanen Pertanian), Dr.Ir. Lilik Pujantoro Eko Nugroho, M.Agr (Departemen Teknik Mesin dan Biosistem, IPB University), Dr.Ir. Emmy Darmawati, M. Si (Departemen Teknik Mesin dan Biosistem, IPB University), Dr. Andasuryani, S.TP, M.Si (Universitas Andalas), Ahmad Thoriq, S.TP, M.Si (Universitas Padjadjaran) 
jiep Jurnal Keteknikan Pertanian 
Technical Paper

\title{
Komposisi Fisikokimia Tepung Ubi Kayu dan Mocaf dari Tiga Genotipe Ubi Kayu Hasil Pemuliaan
}

\author{
Physicochemical Properties of Flour and Mocaf from Three of New Cassava Genotypes \\ Nafilawati Wa Ode, IPB University. \\ Email: nafila040410@gmail.com \\ Emmy Darmawati, Departemen Teknik Mesin dan Biosistem, IPB University. \\ Email: darmawatihandono@gmail.com \\ Sutrisno Suro Mardjan, Departemen Teknik Mesin dan Biosistem, IPB University. \\ Email: kensutrisno@yahoo.com \\ Nurul Khumaida, IPB University. \\ Email: nurul_khumaida@apps.ipb.ac.id
}

\begin{abstract}
This study aims to evaluate the physicochemical composition of cassava flour and mocaf from three cassava genotypes GX, G053 and G390 which are the results of breeding of Crop Improvement IPB Team. Physicochemical composition was performed by measuring water content, carbohydrate, protein, fat, ash, HCN content, yield and white degree. Based on the analysis results it is known that each cassava genotype has different physicochemical composition influenced by the type of genotype and its processing. Physicochemical composition of cassava flour from genotype G053 has yield $(26.10 \% \pm 0.01)$, carbohydrate (89.11\% \pm 0.015$)$, protein $(2.63 \% \pm 0.014)$, highest white degree $(96.89 \% \pm 0.02)$ and lowest water content (6.73\% \pm 0.004$)$. Flour from the G390 genotype had the lowest ash content $(0.74 \% \pm 0.015)$ and fat $(0.59 \% \pm 0.005)$. GX flour has the lowest $H C N$ advantage $(0.40 \mathrm{ppm} \pm 0.198)$. The physicochemical composition of mocaf from the G053 genotype has the advantage of carbohydrate, highest white degree $(98.44 \% \pm 0.02)$ and lowest water content (6.65\% \pm 0.004$)$. Mocaf from genotype G390 has the highest protein (3.01\% \pm 0.018$)$ ash content $(0.28 \% \pm 0.002)$ and lowest fat $(0.57 \% \pm 0.004)$. Mocaf of the GX genotype has the advantage with the highest yield $(28.57 \% \pm 0.08)$ and the lowest $\mathrm{HCN}(0.20 \mathrm{ppm} \pm 0.10)$.
\end{abstract}

Keywords: Cassava, genotipe, flour, mocaf, physicochemical

\begin{abstract}
Abstrak
Faktor penting yang mempengaruhi karakteristik fisikokimia tepung adalah bahan baku tepung, genotipe/ varietas serta proses pengolahan dalam pembuatan tepung. Penelitian ini bertujuan untuk mengevaluasi komposisi fisikokimia tepung ubi kayu dan mocaf dari tiga genotipe ubi kayu yaitu GX, G053 dan G390 yang merupakan hasil pemuliaan Tim Crop Improvement Ubi Kayu IPB. Evaluasi komposisi fisikokimia dilakukan dengan menganalisis kadar air, karbohidrat, protein, lemak, abu, kadar HCN, rendemen dan derajat putih. Berdasarkan hasil analisis diketahui bahwa setiap genotipe ubi kayu memiliki komposisi fisikokimia yang berbeda-beda dipengaruhi oleh jenis genotipe dan proses pengolahannya. Komposisi fisikokimia tepung ubi kayu dari genotipe G053 memiliki keunggulan rendemen $(26.10 \% \pm 0.01)$, karbohidrat $(89.11 \% \pm 0.015)$, protein $(2.63 \% \pm 0.014)$, derajat putih tertinggi $(96.89 \% \pm 0.02)$ serta kadar air terendah $(6.73 \% \pm 0.004)$. Tepung dari genotipe G390 memiliki keunggulan kadar abu $(0.74 \% \pm 0.015)$ dan lemak $(0.59 \% \pm 0.005)$ terendah. Tepung GX memiliki keunggulan $\mathrm{HCN}$ terendah $(0.40 \mathrm{ppm} \pm 0.198)$. Komposisi fisikokimia mocaf dari genotipe G053 memiliki keunggulan yaitu karbohidrat, derajat putih tertinggi $(98.44 \% \pm 0.02)$ dan kadar air terendah $(6.65 \% \pm 0.004)$. Mocaf dari genotipe $\mathrm{G} 390$ memiliki protein $(3.01 \% \pm 0.018)$ tertinggi kadar abu $(0.28 \% \pm 0.002)$ dan lemak terendah $(0.57 \% \pm 0.004)$. Mocaf dari genotipe GX memiliki keunggulan dengan kadar rendemen tertinggi $(28.57 \% \pm 0.08)$ dan $\mathrm{HCN}$ terendah $(0.20 \mathrm{ppm} \pm 0.10)$.
\end{abstract}

Kata Kunci: Ubi kayu, genotipe, tepung, mocaf, fisikokimia

Diterima: 7 Februari 2020; Disetujui: 31 Agustus 2020 


\section{Pendahuluan}

Pesatnya perkembangan berbagai industri berbasis ubi kayu mendorong permintaan ubi kayu yang semakin tinggi pula. Salah satu cara untuk dapat memenuhi kebutuhan ubi kayu di masa mendatang adalah dengan pengembangan varietas ubi kayu melalui pemuliaan tanaman. Seperti yang dilakukan oleh Tim Crop Improvement Ubi Kayu IPB dengan mengembangkan berbagai varian ubi kayu yang mempunyai produktivitas tinggi (Rahmiati 2015). Menurut Khumaida et al. (2015) ubi kayu hasil pemuliaan mempunyai keunggulan pada tingkat produktivitas dan kandungan pati yang tinggi sehingga sangat potensial diolah menjadi tepung ubi kayu dan tepung mocaf (modified cassava flour). Dari sekian banyak varietas atau genotipe ubi kayu yang telah dikembangkan, masih banyak genotipe yang belum diketahui karakteristik produk olahannya sehingga perlu dilakukan analisis untuk mengetahui karakteristik tersebut. Ada 3 genotipe hasil pemuliaan yang masih perlu dikaji karakteristik fisikokimianya yaitu GX, G053 dan G390.

Pembuatan tepung ubi kayu berpeluang untuk dikembangkan di daerah sentra produksi, karena relatif mudah untuk dilakukan dengan peralatan yang sederhana. Selain tepung ubi kayu, produk berbahan baku ubi kayu yang potensial untuk digunakan dalam industri pangan adalah tepung mocaf yang masih merupakan produk turunan dari ubi kayu. Pengolahan tepung mocaf cukup sederhana dan mirip dengan pengolahan tepung ubi kayu biasa, yang membedakan adalah pengolahan tepung mocaf menggunakan prinsip fermentasi oleh bakteri asam laktat.

Ubi kayu memiliki sifat fisik dan kimia yang berbeda-beda, hasil penelitian Susilawati et al. (2008) menunjukan lokasi panen dan umur panen mempengaruhi sifat fisik dan kimia ubi kayu. Charoenkul et al. (2011) juga melaporkan 12 varitas ubi kayu yang berbeda memiliki sifat fisik dan kimia yang berbeda-beda. Menurut Julianti et al. (2011) umur panen yang tepat juga berpengaruh terhadap kualitas tepung yang dihasilkan. Menurut Ariany (2017) dan Rahmiati et al. (2016) genotipe ubi kayu yang berbeda menghasilkan tepung dengan karakteristik yang berbeda pula.

Pengujian karakteristik fisikokimia tepung dari berbagai ubi kayu penting dilakukan karena pemanfaatan tepung ubi kayu dan tepung mocaf dalam pengolahan pangan berbeda-beda tergantung karakteristik fisikokimianya. Karakteristik fisikokimia yang penting untuk diketahui dalam menentukan mutu serta penggunaan tepung adalah rendemen tepung, derajat putih serta komposisi kimia penyusun tepung yaitu kadar air, karbohidrat, abu, lemak dan protein. Penelitian ini diharapkan dapat digunakan sebagai referensi bagi konsumen maupun pelaku usaha berbasis tepung ubi kayu dan tepung mocaf untuk memperoleh gambaran karakteristik dan informasi sifat fisikokimia tepung ubi kayu dan tepung mocaf sesuai dengan tujuan pengolahan tepung.

\section{Bahan dan Metode}

\section{Bahan dan Alat}

Tiga genotipe ubi kayu dengan kode GX, G053 dan G390 yang diperoleh dari Sukamantri dan merupakan hasil pemuliaan Tim Crop Improvement Ubi Kayu IPB, Bimo-CF sebagai starter bakteri asam laktat, alat perajang, rotary dryer, disk mill dan tyler (ayakan) 100 mesh.

\section{Lokasi dan Waktu Penelitian}

Penelitian ini dilaksanakan pada bulan Agustus hingga Desember 2019, bertempat di Lab. Lapangan Siswadhi Soepardjo dan Laboratorium Teknik Pengolahan Pangan dan Hasil Pertanian (TPPHP) Departemen Teknik Mesin dan Biosistem FATETA IPB.

\section{Pembuatan Tepung Ubi Kayu}

Ubi kayu genotipe GX, G053 dan G390 dengan umur panen 9-10 bulan setelah tanam. Ubi kayu segar dipisahkan dari batangnya dan dibersihkan dari kotoran. Ubi kayu dikupas ubi kayu, dicuci bersih dengan air mengalir. Umbi diiris tipis dengan ketebalan 1-2 cm menggunakan alat perajang, dikeringkan dalam rotary driyer pada suhu $\pm 50^{\circ} \mathrm{C}$ sampai kadar air $\leq 12 \%( \pm 10$ jam $)$. Chips kering digiling menggunakan alat disk mill lalu diayak dengan ayakan tyler berukuran 100 mesh. Tepung yang lolos ayakan 100 mesh dianalisis komponen fisikokimianya.

\section{Pembuatan Tepung Mocaf}

Ubi kayu segar dikupas dan dicuci dengan air mengalir. Ubi kayu bersih diiris tipis dengan ketebalan 1-2 cm menggunakan alat perajang. Chips difermentasi selama 12 jam menggunakan starter bimo-CF dengan konsentrasi 1:1:1 (1 kg bahan : 1 liter air : $1 \mathrm{~g}$ Bimo-CF), dikeringkan dalam rotary driyer pada suhu $\pm 50^{\circ} \mathrm{C}$ sampai kadar air $\leq$ $12 \%$ ( \pm 10 jam). Chips kering digiling menggunakan disk mill kemudian diayak dengan ayakan tyler berukuran 100 mesh. Tepung yang lolos ayakan 100 mesh dianalisis komponen fisikokimianya.

\section{Analisis Rendemen Tepung}

Rendemen adalah perbandingan berat kering tepung yang dihasilkan dengan berat ubi kayu segar sebelum dikupas dihitung dengan Persamaan 1.

$R=\frac{b}{a} \times 100$

$$
\text { keterangan: } \begin{aligned}
R & =\text { rendemen }(\%) \\
a & =\text { berat ubi kayu segar }(\mathrm{g}) \\
b & =\text { berat tepung }(\mathrm{g})
\end{aligned}
$$




\section{Pengukuran Derajat Putih}

Derajat putih diukur dengan whietnes meter (Keitth electric labory). Kalibrasi dilakukan dengan standar warna putih $\mathrm{BaSO}_{4}$ yang memiliki derajat putih $100 \%$ (105). Tepung dimasukkan ke dalam wadah khusus, dipadatkan lalu ditutup, kemudian dimasukkan ke dalam tempat pengukuran lalu nilai derajat putih akan keluar pada layar atau terbaca pada alat. Derajat putih tepung dihitung dengan Persamaan 2.

$D_{p}=\frac{A}{105} \times 100$

keterangan :

$D_{p}=$ derajat putih $(\%)$

$A=$ nilai derajat putih yang terbaca pada alat

\section{Analisis Komponen Fisikokimia Tepung}

Metode analisis komponen fisikokimia tepung dapat dilihat pada Tabel 1 .

\section{Analisis Data}

Penelitian ini masih bersifat eksploratif yang hanya melihat perbedaan masing-masing genotipe berdasarkan standar deviasi. Analisis data yang digunakan pada penelitian ini adalah analisis statistika deskriptif. Sampel dianalisis tiga kali pengulangan untuk setiap pengujian. Rata-rata dan standar deviasi setiap analisis ditentukan menggunakan microsoft excel 2013. Deskripsi hasil dianalisis dengan statistika deskriptif menggunakan tabel dan grafik.

\section{Hasil dan Pembahasan}

\section{Rendemen}

Hasil analisis tepung ubi kayu dan mocaf dari 3 genotipe ubi kayu menghasilkan rendemen berbeda-beda (Tabel 2) yaitu berkisar antara $20.97 \% \pm 0.03$ - 28.57\% \pm 0.08 . Rendemen tepung paling tinggi yaitu tepung mocaf dari genotipe GX yaitu $28.57 \% \pm 0.08$, sedangkan tepung ubi kayu dari genotipe G390 memiliki rendemen paling rendah yaitu $20.97 \% \pm 0.03$. Rendemen tepung mocaf lebih tinggi dibandingkan rendemen tepung ubi kayu dari genotipe yang sama disebabkan oleh proses perendaman dan fermentasi dalam pembuatan tepung mocaf. Hal ini sejalan dengan pernyataan Darmawan et al. (2013) yaitu selama proses fermentasi terjadi penghancuran selulosa pada ubi kayu sehingga bertekstur lembut selain itu terjadi pemecahan dinding pada granula pati. Sehingga saat proses penggilingan diperoleh partikel tepung yang lebih halus. Varietas ubi kayu juga berpengaruh terhadap karakteristik mocaf yang dihasilkan, hasil penelitian Wahjuningsih (2013) menunjukkan mocaf dari ubi kayu varietas Adira IV menghasilkan rendemen sebesar 28\%. Pada penelitian ini ubi kayu genotipe G390 memiliki umbi yang lebih keras
Tabel 1. Metode analisis fisikokimia tepung ubi kayu dan mocaf.

\begin{tabular}{ll}
\hline Jenis Analisis & Metode \\
\hline Kadar air & Gravimetri (AOAC 2006) \\
Kadar abu & Gravimetri (AOAC 2006) \\
Kadar lemak & Soxhlet (AOAC 2006) \\
Kadar protein & Kjeldahl (AOAC 2006) \\
Kadar karbohidrat & By different (SNI 01-2891-1992) \\
HCN & Spektro (Eugene et al. 2012) \\
\hline
\end{tabular}

dan berkayu sehingga rendemen tepung yang dihasilkan lebih sedikit dibanding dua genotipe lain. Ariany (2017) menyatakan tepung mocaf dan tepung ubi kayu dari 20 genotipe hasil pemuliaan memiliki rendemen yang berbeda-beda berkisar antara 20.59-29.11\%. Amanu dan Susanto (2014) melaporkan rendemen varietas mentega (47.47\%) lebih besar dari pada varietas karet $(42.66 \%)$ hal ini dikarenakan jenis varietas yang berbeda dapat berpengaruh terhadap rendemen yang dihasilkan. Yulifianti et al. (2012) menyatakan dengan waktu panen umbi pada umur optimal, rendemen mocaf dapat ditingkatkan menjadi 33\% (3000 g umbi segar untuk menghasilkan $1000 \mathrm{~g}$ mocaf).

\section{Derajat Putih}

Derajat putih menunjukkan kemampuan bahan untuk memantulkan cahaya yang mengenai bahan tersebut. Semakin tinggi nilai derajat putih maka semakin putih warna tepung yang dihasilkan. Pengukuran warna tepung sangat diperlukan karena warna dapat mempengaruhi kenampakan produk akhir yang dihasilkan. Hasil pengamatan derajat putih tepung ubi kayu dan tepung mocaf dari 3 genotipe ubi kayu menggunakan alat whitenes meter yang telah dikalibrasi, disajikan pada Tabel 2. Nilai derajat putih berbeda antar genotipe dengan nilai tertinggi pada mocaf dari ubi kayu genotipe G053 yaitu 98.44\%.土0.02, sedangkan hasil pengujian pada tepung ubi kayu dengan genotipe yang sama menunjukkan nilai derajat putih lebih rendah yaitu $96.89 \% \pm 0.02$. Nilai derajat putih mocaf lebih tinggi dibandingkan nilai derajat putih tepung ubi kayu. Menurut Ayetigbo et al. (2018) beberapa faktor yang mempengaruhi warna tepung adalah warna asal umbi, lama proses pengeringan, suhu pemanasan dan proses fermentasi. Pada penelitian ini proses fermentasi diduga menjadi faktor utama yang mempengaruhi perbedaan derajat putih pada masing-masing tepung karena seluruh genotipe ubi kayu yang digunakan merupakan jenis yang sama yaitu umbi putih, selain itu suhu dan lama pengeringan seragam yaitu pada suhu $50^{\circ} \mathrm{C}$ selama 10 jam.

Data derajat putih mocaf dan tepung ubi kayu hasil penelitian sama dengan data derajat putih tepung ubi kayu yang dilaporkan oleh Ariany (2017). 
Tabel 2. Hasil pengukuran rendemen dan derajat putih tepung dari 3 genotipe ubi kayu.

\begin{tabular}{ccccc}
\hline \multirow{2}{*}{ Genotipe } & \multicolumn{2}{c}{ Rendemen (\%) } & \multicolumn{2}{c}{ Derajat putih (\%) } \\
\cline { 2 - 5 } & Tepung ubi kayu & Mocaf & Tepung ubi kayu & Mocaf \\
\hline GX & $24.87 \pm 0.06$ & $28.57 \pm 0.08$ & $92.29 \pm 0.01$ & $93.78 \pm 0.01$ \\
G053 & $26.10 \pm 0.01$ & $27.09 \pm 0.08$ & $96.89 \pm 0.02$ & $98.44 \pm 0.02$ \\
G390 & $20.97 \pm 0.03$ & $25.57 \pm 0.02$ & $89.14 \pm 0.03$ & $90.00 \pm 0.02$ \\
\hline
\end{tabular}

Tabel 3. Komposisi kimia tepung 3 dari genotipe ubi kayu.

\begin{tabular}{ccccccc}
\hline Genotipe & $\begin{array}{c}\text { Kadar Air } \\
(\% \mathrm{bk})\end{array}$ & $\begin{array}{c}\text { Kadar Abu } \\
(\% \mathrm{bk})\end{array}$ & $\begin{array}{c}\text { Kadar Lemak } \\
(\% \mathrm{bk})\end{array}$ & $\begin{array}{c}\text { Protein } \\
(\% \mathrm{bk})\end{array}$ & $\begin{array}{c}\text { Karbohidrat } \\
(\% \mathrm{bk})\end{array}$ & $\begin{array}{c}\text { HCN } \\
(\mathrm{ppm})\end{array}$ \\
\hline $\mathrm{GX}=$ & $7.06 \pm 0.005$ & $1.12 \pm 0.007$ & $0.64 \pm 0.004$ & $2.59 \pm 0.009$ & $88.59 \pm 0.009$ & $0.41 \pm 0.198$ \\
$\mathrm{G} 053$ & $6.72 \pm 0.004$ & $0.78 \pm 0.004$ & $0.76 \pm 0.002$ & $2.63 \pm 0.014$ & $89.11 \pm 0.015$ & $0.80 \pm 0.144$ \\
$\mathrm{G} 390$ & $7.22 \pm 0.015$ & $0.74 \pm 0.003$ & $0.59 \pm 0.005$ & $2.47 \pm 0.013$ & $88.99 \pm 0.009$ & $0.60 \pm 0.110$ \\
\hline
\end{tabular}

Menurut Subagio (2008), tepung mocaf memiliki derajat putih $3-4 \%$ lebih tinggi dibandingkan tepung ubi kayu metode sawut $(88-91 \%$ berbanding $85-$ $87 \%$ ). Hasil pengujian derajat putih genotipe yang dikembangkan lebih putih dibandingkan data derajat putih yang dilaporkan Yulfianti et al. (2011) bahwa derajat putih tepung mocaf klon SM 263-1 adalah $85.7 \%$, lebih tinggi dibanding tepung tanpa fermentasi $(83.0 \%)$.

Perbedaan nilai derajat putih dipengaruhi oleh reaksi pencoklatan yang terjadi selama pengeringan (Darmawan et al. 2013). Sulistyo dan Nakahara (2014) melaporkan perbedaan nilai derajat putih tidak hanya dipengaruhi oleh karakter atau warna awal umbi ubi kayu, akan tetapi juga dipengaruhi oleh proses fermentasi dan proses suhu pemanasan pada tahap pengeringan umbi dalam tahap pembuatan tepung. Suhu pemanasan yang tinggi dan tidak meratanya panas mengakibatkan tingkat kecerahan warna sawut ubi kayu mengalami penurunan. Selain itu komponen kimia dalam bahan dapat mengalami perubahan akibat reaksi yang terjadi antara bahan pangan dengan senyawa lain yang ada di lingkungan misalnya oksigen, uap air dan sebagainya. Kecepatan perubahan ini dapat dipengaruhi oleh $\mathrm{pH}$, aktivitas air bahan, keberadaan enzim atau katalisator (Rahmiati 2015).

Menurut Tandrianto et al. (2014), bakteri asam laktat selama perendaman akan menghasilkan enzim pektinolitik dan selulolitik yang akan menghancurkan dinding sel ubi kayu dan terjadi penghilangan komponen penimbul warna seperti pigmen, dan protein yang dapat memicu browning non enzimatik. Semakin lama perendaman akan menyebabkan semakin berkurangnya komponen penimbul warna, selain itu, pengerokan lapisan lendir juga akan mempercepat laju perkembangan mikrobia dan semakin cepat penghilangan komponen penimbul warna. Selain mempercepat pertumbuhan mikrobia, protein pada lendir ubi kayu (glukoprotein) yang berkurang akan memperkecil terjadinya reaksi maillard.
Rosida dan Nurasih (2008) dan Iswari et al. (2016) melaporkan bahwa semakin lama waktu fermentasi (hingga 3 hari), semakin turun derajat putih tepung yang dihasilkan. Pada penelitian ini, fermentasi dilakukan 12 jam sehingga tepung yang diperoleh lebih putih. Untuk bahan baku tepung, ubi kayu dengan warna ubi putih lebih disukai karena derajat putih merupakan salah satu persyaratan standar mutu tepung (BSN 1996). Menurut BSN (1996), derajat putih tepung ubi kayu minimal $85 \%$ dengan standar $\mathrm{BaSO} 4100 \%$ atau minimal $72.8 \%$ bila menggunakan standar $\mathrm{MgO}$ (85.6\%). Semua tepung yang dihasilkan pada penelitian ini, baik tepung ubi kayu maupun mocaf, telah memenuhi persyaratan SNI.

\section{Kadar Air}

Penurunan kadar air tepung sangat diperlukan karena dapat mempengaruhi umur simpannya. Kadar air yang tinggi akan memicu terjadinya aktivitas mikroorganisme dan reaksi-reaksi kimia yang membuat tepung menjadi cepat rusak sehingga terjadi penurunan mutu. Tepung yang memiliki kadar air tinggi akan menjadi menggumpal dan lengket.

Salah satu proses yang mempengaruhi penurunan kadar air adalah proses pengeringan. Menurut Rasulu et al. (2012) proses pengeringan dengan suhutinggi dapatmempermudah penguapan air pada bahan. Proses pemanasan akan memecah komponen bahan sehingga jumlah air terikat yang terbebaskan semakin banyak sehingga proses pengeringan semakin mudah. Mengacu pada SNI 01-2997-1992 tentang tepung ubi kayu dan mocaf, kadar air tepung dari 3 genotipe ubi kayu (Tabel 3 dan Tabel 4) yang dikembangkan memiliki kadar air kurang dari $9 \%$ dan telah memenuhi standar mutu tepung ubi kayu dan mocaf (Tabel 5 dan Tabel 6) yaitu maksimum 12\% (BSN 1996 dan BSN 2011). Tepung ubi kayu dan mocaf dari genotipe G053 memiliki kadar air paling rendah dibanding genotipe lainnya, tetapi kadar air tepung ubi kayu tidak sama 
Tabel 4. Komposisi kimia tepung mocaf dari 3 genotipe ubi kayu.

\begin{tabular}{ccccccc}
\hline Genotipe & $\begin{array}{c}\text { Kadar Air } \\
(\% \text { bk })\end{array}$ & $\begin{array}{c}\text { Kadar Abu } \\
(\% \text { bk })\end{array}$ & $\begin{array}{c}\text { Kadar Lemak } \\
(\% \text { bk })\end{array}$ & $\begin{array}{c}\text { Protein } \\
(\% \text { bk })\end{array}$ & $\begin{array}{c}\text { Karbohidrat } \\
(\% \text { bk })\end{array}$ & $\begin{array}{c}\text { HCN } \\
(\mathrm{ppm})\end{array}$ \\
\hline $\mathrm{X}$ & $7.07 \pm 0.004$ & $0.70 \pm 0.006$ & $0.72 \pm 0.005$ & $2.82 \pm 0.020$ & $88.69 \pm 0.027$ & $0.20 \pm 0.101$ \\
053 & $6.65 \pm 0.003$ & $0.66 \pm 0.003$ & $0.67 \pm 0.006$ & $2.12 \pm 0.014$ & $89.90 \pm 0.015$ & $0.59 \pm 0.167$ \\
390 & $7.29 \pm 0.001$ & $0.28 \pm 0.002$ & $0.57 \pm 0.004$ & $3.01 \pm 0.018$ & $88.85 \pm 0.014$ & $0.25 \pm 0.071$ \\
\hline
\end{tabular}

dengan tepung mocaf meskipun dari genotipe yang sama. Menurut Kusnandar (2010) tepung dengan kadar air rendah, memiliki umur simpan yang lama.

\section{Kadar Abu}

Kadarabu suatu produkdapatmerepresentasikan kandungan mineral pada suatu produk. Semakin tinggi kadar abu maka semakin tinggi pula kandungan mineralnya (Kusnandar 2010). Pada umumnya ubi kayu hanya sedikit mengandung mineral. Menurut Ayetigbo et al. (2018) melakukan diet hanya dengan mengonsumsi ubi kayu tidak dapat memenuhi kebutuhan mineral harian tubuh. Kandungan mineral dapat dapat berkurang selama proses pengolahan seperti pengupasan, penggilingan dan pemotongan (Failisinur et al. 2015).

Kadar abu tepung ubi kayu lebih tinggi dibandingkan tepung mocaf yaitu berkisar antara $0.74 \% \pm 0.003-1.12 \% \pm 0.007$, sedangkan kadar abu tepung mocaf berkisar antara $0.28 \% \pm 0.002$ $-0.70 \% \pm 0.006$. Pada Tabel 3 dan Tabel 4 dapat dilihat bahwa kadar abu dari tepung ubi kayu dan mocaf sudah memenuhi standar mutu tepung yang ditetapkan (BSN 1996 dan BSN 2011). Genotipe yang berbeda dapat menjadi salah satu penyebab perbedaan nilai kadar abu tepung. Selain itu menurut Ariany (2017) kadar abu pada tepung ubi kayu dan tepung mocaf dari satu genotipe ubi kayu yang sama disebabkan oleh perlakuan selama pengolahan tepung. Proses perendaman (fermentasi) dalam pembuatan tepung mocaf akan menyebabkan larutnya mineral dalam air. Kadar abu yang tinggi pada tepung menyebabkan warna tepung menjadi gelap karena adanya kandungan mineral anorganik yang memiliki ketahanan terhadap suhu tinggi. Semakin rendah kadar abu dalam tepung akan semakin baik karena kadar abu akan mempengaruhi tingkat kestabilan adonan tepung (Ariany 2017).

\section{Kadar Lemak dan Protein}

Hasil analisis lemak pada tepung dari 3 genotipe ubi kayu berkisar antara $0.59 \% \pm 0.008-0.76 \% \pm 0.002$ untuk tepung ubi kayu (Tabel 3) dan $0.57 \% \pm 0.004$ $0.72 \% \pm 0.005$ untuk tepung mocaf (Tabel 4). Kandungan lemak yang tinggi pada tepung ubi kayu berhubungan dengan sifat pasting, kekuatan gel dan karakteristik gelatinisasi dan kekentalan saat pengolahan (Copeland et al. 2009; Hidayat et al. 2007).
Kadar protein pada tepung ubi kayu dan mocaf dari 3 genotipe ubi kayu berkisar antara $2.47-2.63 \%$ (Tabel 3) dan 2.12-3.01\% (Tabel 4). Kandungan lemak, protein dan mineral pada ubi kayu segar dan produk tepungnya merupakan komponen minor sehingga kandungannya relatif rendah. Ukenye et al. (2013) melaporkan perbedaan varietas tidak berpengaruh terhadap kadar protein tepung ubi kayu. Kehilangan protein juga dapat terjadi selama proses pengolahan. Ariany (2017) melaporkan kadar lemak pada tepung ubi kayu dan tepung mocaf dari 20 genotipe ubi kayu tidak lebih dari $2 \%$, sedangkan kadar proteinnya tidak lebih dari $3 \%$. Hal yang sama juga dilaporkan oleh Sulistyo dan Nakahara (2014) hasil analisis kadar lemak dan protein pada tepung ubi kayu dan mocaf tidak lebih dari 3\%. Rahmiati (2015) melaporkan tidak terdapat perbedaan antara kadar protein tepung mocaf dan tepung ubi kayu dari 20 genotipe yang dikembangkan.

\section{Kadar Karbohidrat}

Hasil analisis kadar karbohidrat dengan metode by difference pada tepung dari 3 genotipe ubi kayu (Tabel 3) berkisar antara 88.59\% \pm 0.009 $-89.11 \% \pm 0.015$ dan $88.69 \% \pm 0.027-89.90 \% \pm 0.015$ untuk tepung mocaf (Tabel 4). Kadar karbohidrat dari genotipe yang dikembangkan tidak jauh berbeda dengan kadar karbohidrat pada tepung ubi kayu dan mocaf dari 20 genotipe ubi kayu hasil pemuliaan yang dianalisis oleh Ariany (2017) yang berkisar antara $87.96-91.70 \%$ bk untuk tepung ubi kayu dan $88.15-90.83 \%$ bk untuk tepung mocaf. Rahmiati et al. (2016) juga melaporkan kadar karbohidrat pada 20 genotipe tepung ubi kayu berkisar antara 82.90 $87.29 \%$ bk.

Karbohidrat terbagi menjadi 4 golongan berdasarkan jumlah gula penyusunnya yaitu monosakarida, disakarida, oligosakarida dan polisakarida. Produk tepung berbahan dasar ubi kayu merupakan produk pangan berkalori tinggi karena kandungan karbohirat yang tinggi (80$90 \%$ bk) dan sebagian besar penyusunnya adalah pati (polisakarida) (Montangnac et al. 2009). Kelompok polisakarida (pati) merupakan bentuk karbohidrat komplek yang lebih berperan dalam proses pengentalan, penstabil dan pembentuk gel (Kusnandar 2010). 
Tabel 5. Syarat mutu tepung ubi kayu menurut SNI 01-2997-1996.

\begin{tabular}{lcl}
\hline Jenis uji & Satuan & Persyaratan \\
\hline Bau & & khas ubi kayu \\
Warna & & putih \\
Jenis pati & $\%$ khas ubi kayu \\
Abu & $\%$ b/b & maks. 1.5 \\
Air & $\% \mathrm{~b} / \mathrm{b}$ & maks. 12 \\
Derajat putih & $\% \mathrm{~b} / \mathrm{b}$ & min. 85 \\
Serat kasar & $\% \mathrm{~b} / \mathrm{b}$ & maks. 4 \\
HCN & $\mathrm{mg} / \mathrm{kg}$ & maks. 40 \\
Kehalusan & $\%$ & min. 90 \\
(lolos ayakan 80 mesh) & $\% \mathrm{~b} / \mathrm{b}$ & min. 75 \\
Pati & & \\
\hline
\end{tabular}

Sumber : BSN 1996

\section{Kadar HCN (Hidrogen Sianida)}

Kadar HCN tepung mocaf dan tepung ubi kayu bervariasi (Tabel 3 dan Tabel 4) diduga dipengaruhi oleh proses pengolahan dan genotipe ubi kayu. Kadar HCN pada tepung ubi kayu lebih tinggi (0.41 \pm 0.198 ppm) jika dibandingkan dengan tepung mocaf yang memiliki kadar HCN 0.20 0.101 ppm pada satu genotipe yang sama.

Kandungan $\mathrm{HCN}$ yang tinggi (>100 ppm) dapat menyebabkan keracunan pada konsumen (mual, pusing, muntah), bahkan kematian. HCN dapat dikurangi/dihilangkan selama proses pengolahan karena sifatnya yang mudah larut dalam air dan menguap pada suhu $25.7^{\circ} \mathrm{C}$ (Ginting et al. 2009). Kadar HCN tepung mocaf relatif lebih rendah dibandingkan dengan tepung ubi kayu, karena sebagian besar HCN hilang/terbuang selama proses pengolahan, baik terhidrolisis pada saat fermentasi maupun larut dalam air saat perendaman dan pencucian, dan rusak pada saat pengeringan. Brauman et al. (1996) melaporkan bahwa HCN tereliminasi $>90 \%$ selama 48 jam fermentasi ubi dalam air. Standar mutu tepung ubi kayu (Tabel 5) menetapkan kadar maksimum HCN 40 ppm (BSN 1996), dan standar SNI mocaf (Tabel 6) kadar HCN maksimum 10 ppm (BSN 2011). Tepung yang diolah dari 3 genotipe ubi kayu tersebut, baik tepung mocaf maupun tepung ubi kayu telah memenuhi standar mutu SNI mocaf dan SNI ubi kayu.

\section{Simpulan}

Perbedaan genotipe dan proses pengolahan berpengaruh terhadap komposisi fisikokimia tepung yang dihasilkan. Tepung ubi kayu dan tepung mocaf dari satu genotipe yang sama menunjukkan komposisi kadar air, kadar abu, lemak protein dan karbohidrat yang tidak sama. Rendemen dan derajat putih pada tepung mocaf lebih tinggi dari
Tabel 6. Syarat mutu tepung mocaf menurut SNI tepung mocaf (7922-2011).

\begin{tabular}{lcl}
\hline Jenis uji & Satuan & Persyaratan \\
\hline Bau & & normal \\
Warna & & putih \\
Jenis pati & & khas ubi kayu \\
Abu (b/b) & $\%$ & maks. 1.5 \\
Kadar air (b/b) & $\%$ & maks. 13 \\
Derajat putih & & min. 87 \\
Serat kasar (b/b) & $\%$ & maks. 2.0 \\
HCN & $\mathrm{mg} / \mathrm{kg}$ & maks. 10 \\
Lolos ayakan 100 mesh & $\%$ & min. 90 \\
Lolos ayakan 80 mesh & $\%$ & 100 \\
\hline
\end{tabular}

Sumber : BSN 2011

pada tepung ubi kayu. Kadar HCN tepung ubi kayu maupun tepung mocaf sudah sangat aman untuk dikonsumsi karena semuanya memiliki kadar $\mathrm{HCN}$ dibawah 1 ppm.

\section{Daftar Pustaka}

[BSN] Badan Standarisasi Nasional. 2011. Tepung Mocaf. SNI 7622:2011. http://www.bsn.go.id. [25 Maret 2019].

Amanu, N. F. dan H.W. Susanto. 2014. Pembuatan tepung mocaf di Madura (kajian varietas dan lokasi penanaman) terhadap mutu dan rendemen. Jurnal Pangan dan Agroindustri Vol.2(3):161-169.

AOAC. 2006. Official Method of Analytical of The Association of Official Analytical of Chemist. AOAC. Whasington.

Ariany, S.P. 2017. Karakteristik fisikokimia tepung dari 20 genotipe baru ubi kayu (Tesis). Departemen Teknik Mesin dan Biosistem Fakultas Teknologi Pertanian, IPB. Bogor.

Ayetigbo, O., S. Latif, A. Abass dan J. Muller. 2018. Comparing Characteristics of root, flour and starch of biofortified yellow-flesh and whiteflesh cassava variants, and sustainability considerations: A review. Sustainability Vol.3089(10):1-32.

Brauman, A., S. Keleke, M. Malonga, E. Miambi dan F. Ampe. 1996. Microbiological and biochemical charaterization of cassava retting, a traditional lactic acid fermentation for foo-foo (cassava flour) production. Applied and Environmental Microbiology Vol.62(8):2854-2858.

Charoenkul, N., D. Uttapap, W. Pathipanawatand, Y. Takeda. 2011. Physicochemical characteristics of starches and flours from cassava varieties having different cooked root textures. LWT-Food Science and Technology Vol.44(8):1774-1781. 
Copeland, I, J. Blazek, H. Salman dan M.C. Tang. 2009. Form and functionally of starch. Food Hydrocolloid Vol.23:1527-1534.

Darmawan, M.R., P. Andreas, B. Jos dan S. Sumardiono. 2013. Modifikasi ubi kayu dengan proses fermentasi menggunakan starter Lactobacillus casei untuk produk pangan. Jurnal Teknologi Kimia Industri Vol.2(4):137-145.

Failisinur, Firdausni dan Silfia. 2015. Pengaruh proses pengolahan terhadap sifat fisik dan kimia bubuk kedelai. Jurnal Litbang Industri Vol.5(1):37-43.

Ginting, E., T. Sundari dan N. Saleh. 2009. Ubi kayu sebagai Bahan Baku Industri Bioetanol. Buletin Palawija Vol.17:1-10.

Hidayat, B.A., B. Ahza dan Sugiyono. 2007. Karakterisasi tepung ubi jalar (Ipomea batatas L.) varietas Shiroyutaka serta kajian potensi penggunaanya sebagai sumber pangan karbohidrat alternatif. Jurnal Teknologi dan Industri Pangan Vol.18(1):32-39.

Iswari, K., H. F. Hastuti dan Srimaryati. 2016. Pengaruh lama fermentasi terhadap mutu tepung cassava termodifikasi. Prosiding pada seminar $1^{\text {st }}$ : Membangun Pertanian Modern dan Inovatif Berkelanjutan dalam Rangka Mendukung MEA, Jakarta, Mei 31, 2016. p 1250-1257.

Julianti, E., Z. Lubis, Ridwansyah, Y. Era dan I. Suhaidi. 2011. Physicochemical and functional properties of fermented starch from flour cassava varietas. Asian Journal of Agricultureal Research Vol.5(6): 292-299.

Khumaida, N., S.W. Ardie, M. Dianasari M dan M. Syukur. 2015. Cassava(Manihot esculenta Crantz.) improvement through gamma irradiation. Procedia Food Science Vol.3(1):2734.

Kusnandar, F. 2010. Kimia Pangan: Komponen Makro. Dian Rakyat. Jakarta.

Rahmiati, T.M. 2015. Karakterisasi sifat fisikokimia tepung dan keripik beberapa genotipe ubi kayu (Manihot esculenta Crantz) hasil pemuliaan (Tesis). Departemen Teknik Mesin dan Biosistem Fakultas Teknologi Pertanian, IPB. Bogor.
Rahmiati, T.M., Y.A Purwanto, S. Budijanto dan N. Khumaida. 2016. Penetapan parameter kurva ISA dalam penentuan umur simpan produk pangan kering metode kadar air kritis. Agritech Vol.36(4):459-466.

Rasulu, H., S.S. Yuwono dan J. Kusnadi. 2012. Karakteristik tepung ubi kayu terfermentasi sebagai bahan pembuatan sagukasbi. Jurnal Teknologi Pertanian Vol.13(1):1-7.

Rosida dan A.S. Nurasih. 2008. Kajian konsentrasi bakteri asam laktat dan lama fermentasi padapembuatan tepung pati singkong asam. Agritech Vol.28(3):97-101.

Sulistyo, J. dan K. Nakahara. 2014. Physicochemical properties of modified cassava starch prepared by application of mixed microbial starter. IJRAFS Vol.2(7):1-8.

Susilawati, S. Nurdjanah dan S. Putri. 2008. Karakteristik sifat fisik dan kimia ubi kayu (Manihot esculenta) berdasarkan lokasi penanaman dan umur panen berbeda. Jurnal Teknologi Industri dan Hasil Pertanian Vol.13(2):59-72.

Tandrianto, J., D.K. Mintoko dan S. Gunawan. 2014. Pengaruh fermentasi pada pembuatan mocaf (modified cassava flour) dengan menggunakan Lactobacillus plantarum terhadap kandungan protein. Jurnal Teknik Pomits Vol.3(2):143-145.

Ukenye, E., U.J. Ukpabi, U. Chijoke, C. Egesi dan S. Njoku. 2013. Physicochemical, nutritional and processing properties of promising newly bred white and yellow fleshed cassava genotypes in nigeria. Pakistan Journal of Nutrition Vol.12(3):302-305.

Wahjuningsih, S.B. 2013. Inovasi teknologi pengolahan ubi kayu menjadi tepung mokaf, peluang dan tantangan pengembangannya di Jawa Tengah. Prosiding pada seminar nasional : Inovasi dan Technopreneurship. IPB International Convention Center, Bogor, Februari 18-19, 2013. p 1-7.

Yulifianti, R., E. Ginting dan S.J. Utomo. 2012. Tepung kasava modifikasi sebagai bahan substitusi terigu mendukung diversifikasi pangan. Buletin Palawija Vol.2012(23):1-12. 
Halaman ini sengaja dikosongkan 


\section{Indeks Penulis}

Jurnal Keteknikan Pertanian Volume 8 Tahun 2020

Abdullah bin Arif, 29

Ahmuhardi Abdul Azis, 45

Andi Ani Kuswati, 15

Ari Hayati, 81

Armansyah Halomoan Tambunan, 39, 53, 89

Bambang Pramudya, 63

Budi Santoso, 113

Dadan Kusdiana, 39

Darma, 113

Desrial, 89

Dwi Zuwarman, 1

Edy Hartulistiyoso, 39, 53

Emmy Darmawati, 15, 63, 97, 105

Evi Savitri Iriani, 71

Fajar Kurniawan, 71

Hasbi, 81

Hendri Syah, 53

Herbert Hasudungan Siahaan, 89

I Dewa Made Subrata, 9

I Wayan Budiastra, 45

Inge Scorpi Tulliza, 39
Lamhot Parulian Manalu, 53

Marisa Tri Amanah, 81

Nafilawati Wa Ode, 97

Nurul Khumaida, 97

Reniana, 113

Riska Juliana, 23

Rismen Sinambela, 9

Rokhani Hasbullah, 1, 23

Sandro Pangidoan Siahaan, 29

Sari Intan Kailaku, 29

Soni Solistia Wirawan, 89

Siti Mariana Widayanti, 15

Sri Lestari, 71

Sutrisno Suro Mardjan, 1, 23, 45, 63, 97, 105

Syamsul Bahri, 63

Tatang Hidayat, 29

Tineke Mandang, 9

Usman Ahmad, 71

Wawan Hermawan, 9

Yandri Iskandar Pah, 105 


\section{Indeks Subjek}

Jurnal Keteknikan Pertanian Volume 8 Tahun 2020

ASLT Method, 23

Biodiesel, 39

Biogas, 89

Catalyst, 39

Curing, 29

Cylinder type, 113

Distribution centers, 63

Dormancy, 29

Drying model, 53

Drying rate, 53

Edible coating, 105

Energy ratio, 39

Engine performance, 89

Expiration date, 23

Exposure duration, 15

Extraction, 45

Fresh Fruit Bunch, 9

Genotipe, 97

Good Handling Practices, 1

Good Manufacturing Practices, 1

Growth power, 29

Hellical barrier, 89
Immersion temperature, 81

Irradiation, 71

Moisture sorption isotherm, 23

Oil palm, 9

Oleoresin, 45

Optimum Ripeness Position, 9

Ozon, 15

Peleg model, 81

Physicoshemical, 97

Rasping performance, 113

Rehydration, 81

Rice Milling Unit, 1

Rotation speed, 113

Static mixer reactor, 39

Storage, 29, 71

Teeth diameter, 113

Temperature, 29

Thin layer drying, 53

Total Plate Count, 15

Ultrasound, 45

Yield, 45 